\title{
RESENHANDO A FESTA DA JAGUATIRICA...
}

JEFFERSON VIRGÍLIO ${ }^{1}$

UNIVERSIDADE DE LISBOA

\section{RESENHA}

MENEZES BASTOS, Rafael José de. A festa da jaguatirica: uma partitura crítico-interpretativa. Florianópolis: Editora da UFSC, 2013. 524 p.

Sometimes even in the habitual course of life, the reality of this world disappears all at once, and we feel ourselves in the middle of its interests as we should at a ball, where we did not hear the music; the dancing that we saw there would appear insane. (STAËL, 1814, p. 296)

Apesar de o autor explicitar descrever apenas um ritual musical xinguano de onze dias em $A$ festa da jaguatirica, o livro é parte dos resultados da pesquisa e do longo convívio do etnomusicólogo com discursos e práticas dos Kamayurá do Alto Xingu, com o texto de inspiração academicamente compreendido como uma tese de doutoramento. Em muito a proposta dialoga com o exposto em $A$ musicológica Kamayurá, onde a origem textual é descrita na academia como uma dissertação de mestrado, que foi publicada como livro pela Funai (1978) e pela EdUFSC (1999).

Estando eu contemplado por valores expostos por Seeger no prólogo, e pela apresentação dos capítulos de Rafael entre as páginas 26 e 27, além da descrição feita em traços de vista musicais por Piedade (2014), me aterei ao levantamento das críticas etnográficas e antropológicas que o etnomusicólogo constrói durante a obra, sendo elas complementadas por reposicionamentos que pratica na disciplina.

É corrigido a quem lê, na revisão bibliográfico-histórica, que etnomusicologia não é nem uma parte de antropologias, nem uma parte

\footnotetext{
${ }^{1}$ Instituto de Ciências Sociais da Universidade de Lisboa. E-mail: jv@ia.edu.pt
} 
de musicologias, enquanto se destacam os potenciais efeitos nocivos deste conjunto de limites arbitrariamente (ou não) impostos. São adicionadas correções sobre incorporações, limitações e separações não desejadas. Destaque devido à errônea quebra (e hierarquização) entre música e fala, e a criticável restrição das etnomusicologias serem sujeitas a estudar apenas recortes de tipos de música, sejam étnicos, espaciais ou temporais.

O autor explicita a infeliz desigualdade de valor impressa entre a arte e a ciência e das criadas confusões nas relações de permuta possíveis entre técnica, progresso, inteligibilidade e racionalidade. Os devidos créditos à semente do que hoje é a etnomusicologia à Merriam são fartos. Por fim, alerta, com décadas de antecipação, o saber que jamais fomos modernos ocidentais.

Não satisfeito em reaplicar o contraste proposto por Roberto Cardoso de Oliveira (1976, p. 5-6) em um diferente contexto de análise, o autor o transcende para outro nível, e no deslocamento problematiza contrastes entre campos de saber diferenciados. Rompe (e vence) o paradigma musicológico, assim como o dilema antropológico, que são construídos ao sugerir uma antropologia da etnomusicologia (MENEZES BASTOS, p. 35-63).

A descrição de partes mínimas ao todo do Yawari é o que permite a quem lê atingir a percepção sobre a cultura, o mito e a música. E da impossibilidade de separar ou eliminar as categorias na análise, se deseja de fato praticar ali alguma antropologia. Desde a evidência de desentendimentos prévios à execução do ritual para o respectivo, até os limites que o ritual é nas relações sociais cotidianas. Detalhes de brigas entre ajudante e mestre rituais enriquecem este valor na etnografia. De definições de gênero e parentesco à geração, às diferenças étnicas, e limites entre nós e eles. É a estrutura que é estruturante sendo estruturada pelo que estrutura. E durante o Yawari que são definidos e redefinidos os tempos, os espaços e as sociabilidades kamayurá.

A argumentação que é tecida ao propor relações entre mito e música (e cultura) permite, quando dada devida atenção, corrigir a dupla (diria múltipla) falha, já propagada, com e sem desvios: Em primeiro lugar as mitológicas ameríndias não "estão para" as filosóficas ocidentais ${ }^{3}$. As mitológicas ameríndias são representações de culturas, onde as músicas ameríndias são outras representações. Em segundo lugar, as filosóficas ocidentais são, similarmente, representações de culturas, onde as músicas ocidentais são outras representações. As músicas ameríndias (e por isso os múltiplos erros do mitólogo francês) ${ }^{4}$ assim "estão para" músicas ocidentais. E com mínimo esforço, alguém pode perceber que as culturas ameríndias "estão para" as culturas ocidentais, sendo relacionais, mas não necessariamente permutáveis ou comparáveis entre si. A análise estrutural das sequências do ritual musical é que permite Rafael aprender

\footnotetext{
${ }^{3}$ Opto por limitar, reduzindo, a contragosto, a termos derivados de ameríndia e ocidente, simplificando.

${ }^{4}$ Claude Lévi-Strauss. Com destaque para as Mitológicas, por exemplo, em 1964 (volume I) e em 1971 (volume IV).
} 
com o outro e, discretamente (p. 218 , nota 150), ressalta a amplitude da complexidade de sua aplicação; além de que em clara distinção a do tal francês, esta escrita é enfim etnográfica.

Como a pesquisa nasce da nota de rodapé de um terceiro, convém destacar umas mais: ainda discretamente (p. 51, nota 26), o autor evidencia a total incapacidade do mitólogo em perceber a etnomusicologia, ao invisibilizar a música: "aquilo é muito chato, é tudo igual”. E ilustra a influência de filósofos ( $p$. 80, nota 56) na construção negativa de valor da música. E a superioridade de forma e (re)uso da música xinguana (p. 81, nota 58 ) perante aquilo que compreende ser alguma música europeia.

Rafael também demonstra como a (ir)racionalidade dominante na etnomusicologia ${ }^{5}$ é que pode ser a culpada, ao não ser o quebra-cabeça visto por etnomusicólogos. E permite assumir que com o ponto de vista apreendido, agora discutido por etnomusicólogos, a situação pode ser revista. A descrição aritmética de Rafael da construção do Yawari comprova que não apenas tais indígenas não podem ser reduzidos a um pensamento pré-lógico, como o pensamento (e a memória) destes selvagens são per si complexos sistemas de organização social, dotados de incomparável dimensão, além de espectro de alcance alargado.

Questionar indevidas projeções de valia relacional entre arte e ciência, ou populações indígenas e não indígenas, são outros incentivos que o etnomusicólogo proporciona aos leitores do ritual. Fica, ao final de uma leitura (atenta) d'A festa da jaguatirica, evidenciada a real possibilidade de prática antropológica distinta, em aprender com o outro, e de prática etnográfica, ao descrever o outro, pelos suportes singulares ofertados pela etnomusicologia.

\section{Referências adicionais}

CARDOSO DE OLIVEIRA, Roberto. "Identidade étnica, identificação e manipulação". Identidade, etnia e estrutura social. São Paulo: Pioneira, 1976. p. 1-31.

LÉVI-STRAUSS, Claude. Le cru et le cruit. Paris: Plon, 1964.

L'homme nu. Paris: Plon, 1971.

MENEZES BASTOS, Rafael José de. A musicológica Kamayurá: para uma antropologia da comunicação. Florianópolis: Editora da UFSC, 1999 [1978].

PIEDADE, Acácio. Reseña de Menezes Bastos, Rafael José de. A festa da jaguatirica:

\footnotetext{
${ }^{5}$ Dado que o autor parte de estudos e nomes iniciais, antes da classificação e da nomenclatura atuais da etnomusicologia, e sugere uma revisão do termo. Restrinjo as chamadas a este único, finalista.
} 
uma partitura crítico-interpretativa. El oído pensante, Buenos Aires, v. 2, n. 1, p. 1-8, 2014.

STAËL, Anne Louise Germaine de. "On the Moravian mode of worship". The universal magazine of knowledge and pleasure, Londres, v. 21, ed. 125, p. 296-298, abr. 1814.

Recebido em: 08/07/2018 * Aprovado em: 15/12/2018* Publicado em: 27/06/2019 